\title{
Administrative Challenges and Practices of Civil Service Reform Implementation: The Case Haro Limu District in Oromia Region
}

\author{
Lelisa Kebede Tolera \\ Lecturer of Governance and Development Studies at Mettu University \\ College of Social Science and Humanities \\ Mettu, Ethiopia
}

\begin{abstract}
The main objective of this study is to examine administrative challenges in the implementation of civil service reform in Haro Limu District. In order to achieve this objective, descriptive research design and combination of quantitative and qualitative research approach was employed. In this study, the researcher used both primary and secondary sources of data. Primary data were gathered through questionnaire, interview and focus group discussion while secondary data were gathered from books, journals, articles both published and unpublished and official documents from Haro Limu District. Questionnaires were distributed and administered by the researcher with the help of enumerators. Structured questionnaires were filled by the sample respondents from five selected civil service sectors. Interviews were conducted with five management officials from five selected public offices to attain profound information. Similarly, FGD was conducted with employees selected purposively from civil service sectors. Data collected from different sources were analyzed and interpreted through quantitative and qualitative techniques. The finding of the study identified some interrelated administrative challenges in the implementation of CSR in the study area. These are low commitment and competency of management officials; lack of accountability and low cooperation between management officials and employees; low recognition of reform standards; lack of professionalism, lack of fair selection, evaluation and promotion of employees and lack of advanced measurement standards; lack of adequate training, lack of incentives or rewards and regular supervision. Based on the identified problems, the following possible recommendations were provided. Strengthening capacity building, enhancing the cooperation between management officials and employees, ensuring accountability of management officials and employees, enhancing human resource management, allocating adequate budget, promoting effective communication between public sectors and strengthening regular supervision and monitoring for the effective implementation of civil service reform in the study area.
\end{abstract}

Keywords: civil service reform, implementation, administrative challenges and practices

DOI: $10.7176 / J P I D / 60-02$

Publication date:July $31^{\text {st }} 2021$

\section{INTRODUCTION}

Civil service reform is the most comprehensive areas of public administration adopted by both developing and developed countries of the world. The ever increasing change in economic, social, political, and technological environment has demanded more efficient and effective management systems (Solomon, 2013). This in practice, led to the need for the governments to implement civil service reform to reduce the cost of the civil service and create skilled and efficient workforce which is critical for governance, production and distribution of public goods and services, formulation and implementation of economic policy, and management of public expenditure (Lukumai, 2006).

Despite its global spread, the implementation process of CSR became complex due to different reasons like rearranging difficult human configurations and changing human behavior (Rafiqur, 2001). In addition, most of African countries are forced to implement civil service reforms under the guidance of international organizations like WB and IMF and the prevalence of socio-political upheavals which in turn resulted in institutional incapacity (Paulos, 2001). In Ethiopia the purpose of reforming the old civil service system under FDRE was to avoid the undesired practices that hindered effective and efficient public service delivery and to maintain civil service system with the changing circumstances. Thus, in realizing this objective, the current government of Ethiopia had adopted three important and comprehensive policy reforms; changing the political ideology from socialist to federal system; building a capable civil service to provide citizens with friendly service delivery, and improving quality service delivery which is still under process (Abeje Tafere and Narayana, 2015).

Despite the above stated policy reforms, the implementation of civil service reform in Ethiopia in general and Oromia Regional State in particular face several challenges. On this many research works have been done by different researchers. Solomon (2013), "Civil Service Reform in Ethiopia: Issues, Lessons, and Future Directions", Gebre and Melesse (2014), "The Implementation of Civil Service Reforms in Ethiopia: The Promise for Civil Service De-Politicization of Tigray National Regional State" and Libanos, et.al (2014), on "The Implementation of Recruitment and Selection in Civil Service Institutions of Oromia Regional State". However, 
none of these studies gave attention to the administrative challenges of civil service reform implementation at district level. Thus this study is intended to examine challenges and practices of civil service reform implementation in Haro Limu District.

\section{Research Design}

For the purpose of this study, descriptive research design was employed. The rationale of employing descriptive studies stems from the fact that such studies describe the state of affairs as it exists at present (Kothari, 2004). In addition, the researcher used combination of both quantitative and qualitative research approaches since these approaches provide a researcher with a pool of data that gives broad base to the findings of the study and helps the study to be more valid, reliable, and dependable (Creswell and Clark, 2007).

\section{Sources of Data}

To attain the objective of this study, both primary and secondary data has been used. The Primary data was gathered from sample respondents and secondary data was collected from books, journals, published and unpublished articles, and official documents from the study area.

\section{Study Population and Sample Size}

Study Population: Study population is an aggregation of elements from which the sample is actually selected. Accordingly, the study population of this study was all permanent employees which are currently working in five public offices of Haro Limu district. Sample size: for this study 103 employees were selected by simple random sampling method. In addition, five employees were sampled purposively from the selected five offices of the district.

\section{Method of Data Collection}

For the successful achievement of its objectives this study employed questionnaire, interview and focus group discussion as instruments of collecting data from primary sources. Besides the researcher reviewed different materials for collecting data from secondary sources.

\section{Method of Data Analysis}

Data collected from primary and secondary sources were recorded, edited, organized, analyzed, interpreted and presented in relation to research questions. The data collected through questionnaire was analyzed quantitatively by using descriptive statistical tools such as tables, figures, percentages, graphs and charts, whereas data collected through interview and focus group discussion was analyzed qualitatively.

\section{Administrative Challenges in the Implementation of Civil Service Reform in Haro Limu District 1. Low of Commitment of management officials} Figure 1. Respondents' Opinion on Management Official's Commitment

Are management officials committed for the implementation of civil service reform?

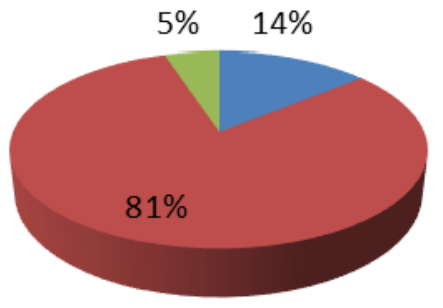

$$
\begin{aligned}
& \text { Yes } \\
& \text { No } \\
& \text { I don't know }
\end{aligned}
$$

\section{Source: Researcher's Own Survey Results, March 2016}

The Figure 4.1 above indicated that $14.1 \%$ of the respondents replied 'yes' and majority $(80.8 \%)$ of respondents replied 'no' on whether management are committed in the implementation of CSR. While the rest $5.1 \%$ of respondents replied as they are not sure of whether top management officials are committed or not to the implementation of civil service reform. On the same issue, one of the key informants from civil servants (March, 2016) said that, ".... top management officials are not commitment since they have no clear understanding on the importance reform program".

In addition, as the key informants from management officials suggested the commitment of civil servants on the implementation of reform process is not as it is expected. This is due to lack of understanding about the 
purpose of the reform program and lack of rewards and initiative environment. As focus group discussants said, unequal benefit among civil servants working in different sectors by having equal academic status is the major cause for the low commitment of civil servants towards civil service reform.

Therefore, one can say that low commitment of top management officials and civil servants is a considerably affecting implementation of civil service reform in Haro Limu district.

\section{Low of Cooperation between Management Officials and Employees}

Table 1. Respondents' Opinion on Cooperation between Management Officials and Employees

\begin{tabular}{|l|l|l|l|}
\hline Item & Responses & Frequency & Percent \\
\hline \multirow{2}{*}{$\begin{array}{l}\text { How do you think the cooperation between } \\
\text { management officials and employees regarding civil }\end{array}$} & V. High & --- & --- \\
\cline { 2 - 4 } service reform implementation? & High & 7 & 7.1 \\
\cline { 2 - 4 } & Medium & 31 & 31.3 \\
\cline { 2 - 4 } & Low & 43 & 43.4 \\
\cline { 2 - 4 } & V. Low & 18 & 18.2 \\
\cline { 2 - 4 } & Total & 99 & 100 \\
\hline
\end{tabular}

Source: Researcher's Own Survey Results, March 2016

The above Table reveals that, $7.1 \%, 31.3 \%$ and $43.4 \%$ of respondents replied high, medium and low on the level of cooperation between management officials and employees. The rest $18.2 \%$ of the respondents replied as the cooperation between management officials and employees is very low. In consistent with the above question, the FGD participants also commented that, management bodies give more focus to the political accountability than civil service reform program. This result in mistrust between the two bodies and employees are ceased to closely work with top management officials. In other words there is no mutual understanding between some management officials and employees due to some officials consider themselves as boss rather than coworkers. From the above responses we can conclude that, low cooperation between civil servants and management officials affects the implementation CSR implementation in the study area.

\section{Low Competency of Management Officials and Civil Servants}

Table 2. Respondents' Opinion on the Competency of Management Officials

\begin{tabular}{|l|l|l|l|}
\hline Items & Responses & Frequency & Percent \\
\hline $\begin{array}{l}\text { Do management officials competent } \\
\text { enough in performing all }\end{array}$ & Yes & 41 & 41.4 \\
\cline { 2 - 4 } responsibilities expected from them? & No & 49 & 49.5 \\
\cline { 2 - 4 } & I don't know & 9 & 9.1 \\
\cline { 2 - 4 } & Total & 99 & 100 \\
\hline
\end{tabular}

Source: Researcher's own survey results, March 2016

Competency of management official is one of the most important factors to increase agency effectiveness (Rainey and Steinbauer (1999:3). In connection with this, survey result on the above Table 4.5 shows, $41.4 \%$ and $49.5 \%$ of the respondents replied Yes and No on the issue whether management officials are competent enough in performing all responsibilities given to them. The rest $9.1 \%$ of the respondents replied as they don't know whether management officials are competent enough or not. In addition, FGD participants suggested that, most top management officials are not competent in executing their duties. They commented different reasons for the incompetency of management officials like political loyalty, personal relationship and year of experience rather than academic status as criteria when coming to management position. They said that, there are peoples on management position with diploma level.

Regarding the competency of civil servants, key informant interviewees suggested that, there are many people waiting for the support of other person in performing his/her duties or try to make their duty of another person. In this condition it is difficult to realize the reform program in general and in the study area in particular.

\section{Lack of Accountability}

Figure 2. Respondents' Opinion on the Accountability of Management Officials

\begin{tabular}{|l|l|l|l|}
\hline Items & Responses & Frequency & Percent \\
\hline \multirow{2}{*}{$\begin{array}{l}\text { Do management officials } \\
\text { accountable for failure of their }\end{array}$} & Yes & 41 & 41.4 \\
\cline { 2 - 4 } activities? & No & 51 & 51.5 \\
\cline { 2 - 4 } & I don't know & 7 & 7.1 \\
\cline { 2 - 4 } & Total & 99 & 100 \\
\hline
\end{tabular}

Source: Researcher's own survey results, March 2016

As shown in the Table 4.3 above, $41.4 \%$, and $51.5 \%$, of the respondents replied yes and no respectively on the accountability of management officials. The rest $7.1 \%$ of the respondents have no idea on whether 
management officials are accountable or not. In addition, participants in FGD stated as the management officials are not accountable for their misconduct ad failure of their activities. One focus group discussant told that, "...the accountability of management officials in public office is not as much as it is told orally. Practically I didn't see when officials are punished for their misconduct; even when their wrong action is exposed". From this we can deduce that implementation of CSR reform is affected by low accountability of management officials in the study area.

\section{Low Recognition of Reform Standards}

Table 4. Respondents' Opinion on the Reform Standards

\begin{tabular}{|l|l|l|l|}
\hline \multicolumn{1}{|l|}{ Item } & Response & Frequency & Percent \\
\hline $\begin{array}{l}\text { Are the standards of civil service reform } \\
\text { recognized among all civil servants in your } \\
\text { office? }\end{array}$ & Yes & 21 & 21.2 \\
\cline { 2 - 4 } & No & 78 & 78.8 \\
\cline { 2 - 4 } $\begin{array}{l}\text { If your answer is No on the above question, is it } \\
\text { because of; }\end{array}$ & Total & 99 & 100 \\
\cline { 2 - 4 } & Shortage of time & 29 & 37.2 \\
\cline { 2 - 4 } & Lack of materials & 31 & 39.7 \\
\cline { 2 - 4 } & lack of job standard documents & 18 & 23.1 \\
\cline { 2 - 4 } & Total & 78 & 100 \\
\hline
\end{tabular}

Source: Researcher's Own Survey Results, March 2016

As indicated in the Table 4.6 above, $21.2 \%$ of them replied positively as the standards of civil service reform are recognized among civil servants while $78.8 \%$ of the respondents answered as the standards are not recognized. In connection with their opinion on the above question, the respondents who said 'No' were again requested to identify the reason for why civil servants fail to recognize civil service reform standards. Accordingly, $37.2 \%, 39.7 \%$ and $23.1 \%$ of the respondents replied shortage of time in relation to work loads, lack of materials and lack of job standard documents respectively as the major factor for civil service reform standards. Thus we can suggest that low recognition of reform standards due to above mentioned problems is the cause for the ineffectiveness of civil service reform in the study area.

\section{Lack of professionalism}

Figure 2. Respondents' Opinion on professionalism in office

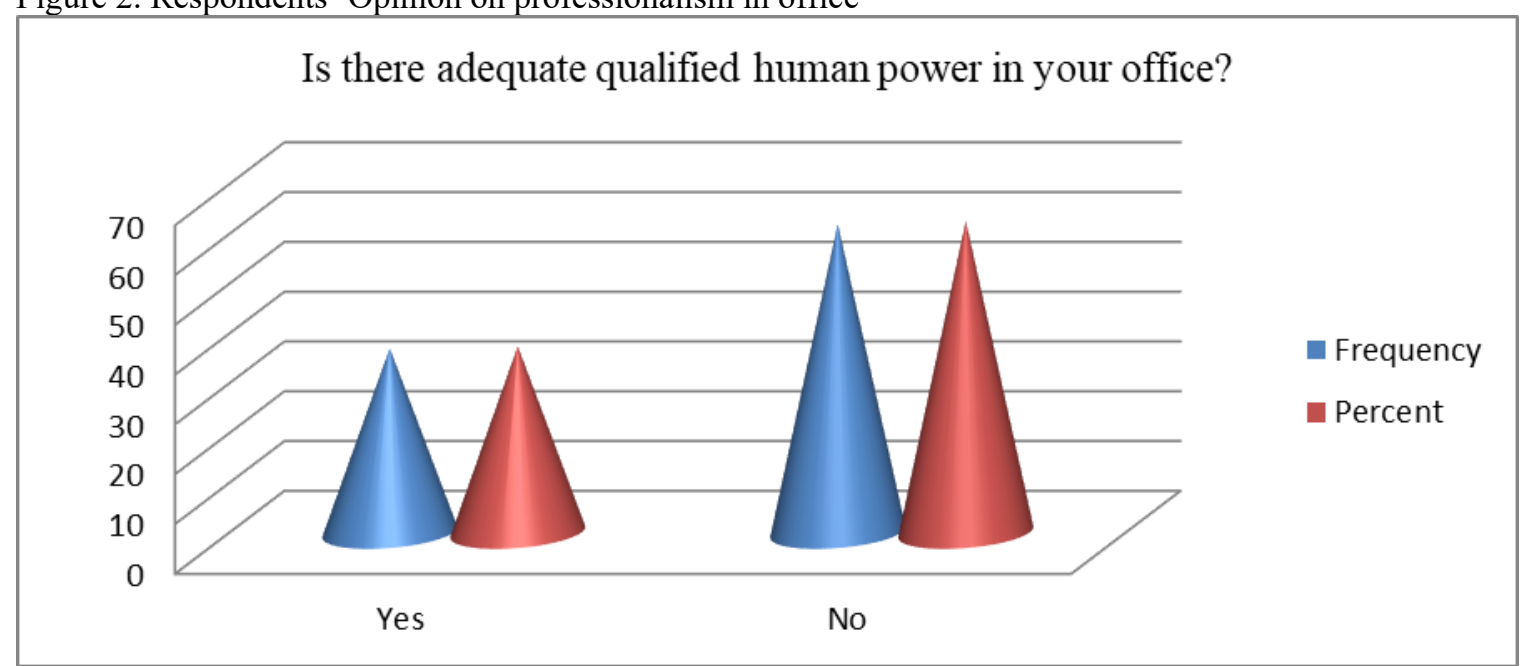

Source: Researcher's own survey results, March 2016

As indicated by figure above, only $37.4 \%$ of the respondents replied 'Yes' and the rest $62.6 \%$ replied 'No' regarding presence of professionalism in their respective office. In addition most of the FGD and interview participants suggested as their place where they work, is irrelevant with their area of qualification. Thus it is possible to say that inconsistency of employee's qualification and the duty they have in office unquestionably affect the implementation of CSR in the study area. 
7. Lack of Fair Selection of Employees

Table 5. Respondents' Opinion on Selection of Employees

\begin{tabular}{|l|l|l|l|}
\hline Item & Responses & Frequency & Percent \\
\hline \multirow{2}{*}{ Is the selection of employees based on merit system? } & Yes & 47 & 47.5 \\
\cline { 2 - 4 } & No & 52 & 52.5 \\
\hline & Total & 99 & 100 \\
\hline If your answer is 'No' on the above question, is it based on; & political view point & 20 & 38.5 \\
\cline { 2 - 4 } & Personal Relationship & 32 & 61.5 \\
\cline { 2 - 4 } & Giving Bribe & --- & --- \\
\cline { 2 - 4 } & Total & 52 & 100 \\
\hline
\end{tabular}

Source: Researcher’s Own Survey Results, March 2016

As the above Table indicates, $47.5 \%$ of the respondents answered 'Yes' and $52.5 \%$ respondents replied 'No' on whether employees' selection is based on merit system. Respondents whose answer is 'no' were again requested to answer the other criteria up on which the selection of employees is based. Accordingly, 38.5\%, $61.5 \%$ of the respondents replied political background and personal relationship respectively.

In contrast, some of the key informant interviewees from management officials have suggested that the selection of employees is fair and based on open competition. Here the response gained from civil servants through questionnaire survey and management officials through personal interview is almost contradicting each other. Furthermore, FGD participants were also requested to explain the same issue during discussion and majority of the discussants point out on the existence of problem regarding employees' selection. On this issue one discussant (March, 2016) said that, “...there are some individuals who were employed without having any academic status. If the employees' selection process is really based on applicant's competency and open competition, there is no way the person to be hired without having legal documents in public office". According to article 12(3) of Ethiopian Federal Civil Servants Proclamation No. 515/2007, vacancies may be filled through recruitment, promotion, and transfer on the basis of the human resource plan. In addition, under article 13 sub article (1\&2) it is sated that, there shall be no discrimination among job seekers or civil servants in filling vacancies because of their ethnic origin, sex, religion, political outlook, disability or any other ground and a vacant position shall be filled only by a person who meets the qualification required for the position and scores higher than other candidates. Thus based on the above stated evidence and legal principles unfair selection of employees is factor affecting implementation of civil service reform in Haro Limu district.

\section{Lack of Fair Evaluation and Promotion}

Figure 3. Respondents' Opinion on Evaluation and Promotion of Civil Servants

\section{Is there fair evaluation and promotion of civil servants in your office?}

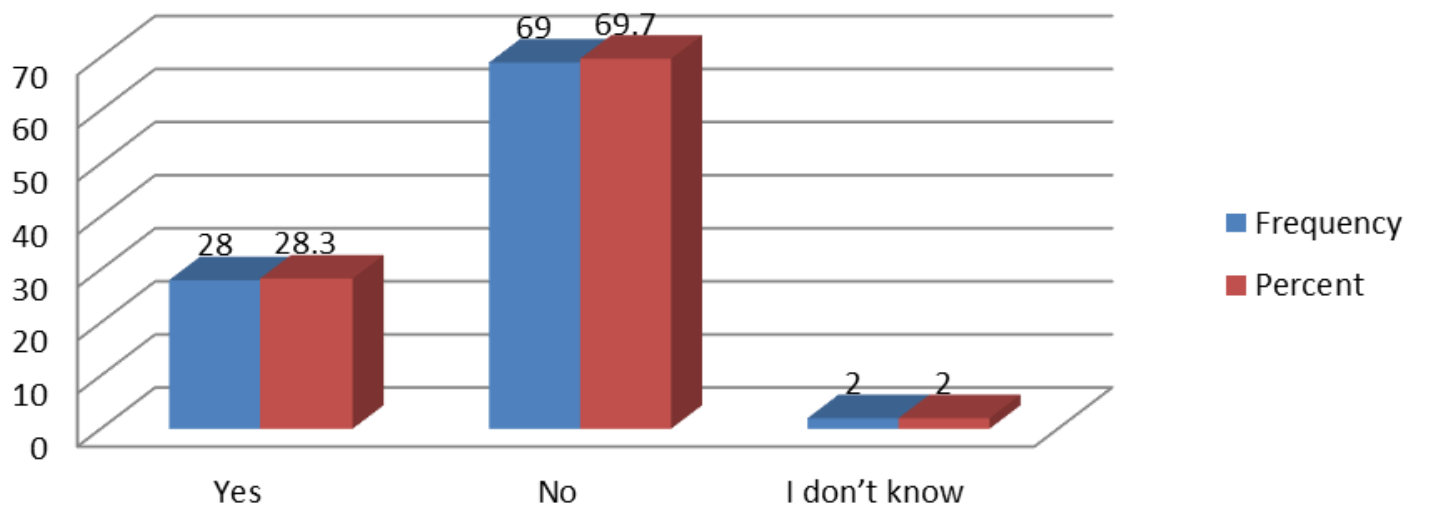

Source: Researcher's Own Survey Results, March 2016

As it is shown by the above figure 4.5 , only $28.3 \%$ of the respondents replied as the evaluation and promotion of public employees is fair, whereas $69.7 \%$ of respondents replied it is not. The rest $2 \%$ of the respondents failed to say 'Yes' or 'No' whether the evaluation and promotion of public employees is fair. In connection with this, one discussant argued that "...most of the time our performance evaluation is not fair and hence didn't show us our exact strength and weakness. Thus our promotion is also determined in accordance with the way we were evaluated." From the above view point one can easily understand as unfair evaluation and promotion of civil servants exist in the study area which in turn affect the implementation of civil service reform. 
10. Lack advanced Measurement standards

Figure 4. Respondents' Opinion on performance indicators

\section{Is there well developed measurement criterion in your office?}

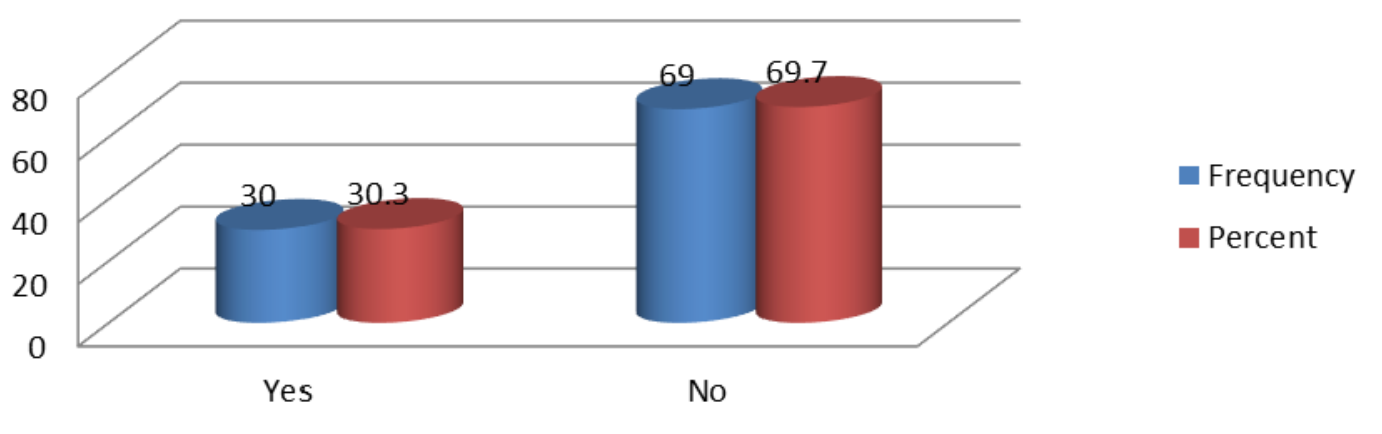

Source: Researcher's Own Survey Results, March 2016

As the result from the above Figure indicates, the majority of the respondents have negative inclination on the presence of advanced measurement standards. Only $30.3 \%$ respond positively. In relation to the above question, most of the focus group discussants suggested that measurement standards in their offices are poor and they were being evaluated by the old standards. Paulos, (2001:99) pointed out that, setting measurement criterion for activities in the public sector will be a difficult and demanding task due to incapacitated and demotivated civil servants, lack of facilities and poor information systems. As the result, lack of advanced measurement standards is one of the major factors affecting the implementation of civil service reform in the study area.

11. Lack of Incentives and Rewards

Table 6. Respondents' Opinion on Provision of Incentives for Civil Servants

\begin{tabular}{|l|l|l|l|}
\hline \multicolumn{1}{|c|}{ Item } & Responses & Frequency & Percent \\
\hline Is there incentive or reward provided for civil & Yes & -- & -- \\
\cline { 3 - 4 } servants performing their duties in your office? & No & 99 & 100 \\
\cline { 2 - 4 } & Total & 99 & 100 \\
\hline
\end{tabular}

Source: Researcher's Own Survey Results, March 2016

As the result from Table 4.12 shows, all of the respondents replied as there is no any incentive and reward provided for civil servants for properly performing their duties. Furthermore, most of the key informant interviewees suggested that, no one is rewarded for his/her high performance till now. Such kind of working conditions makes the hard workers only to use their minimum effort in executing duties. Thus it can be concluded that absence of incentive and reward for employees for their higher achievement is affecting the implementation of civil service reform in the study area.

\section{Lack Adequate Training}

Table 7. Respondents' Opinion on Training

\begin{tabular}{|l|l|l|l|}
\hline Items & Responses & Frequency & Percent \\
\hline \multirow{2}{*}{$\begin{array}{l}\text { Are you given adequate training on civil } \\
\text { service reform implementation? }\end{array}$} & Yes & 34 & 34.3 \\
\cline { 2 - 4 } & No & 65 & 65.7 \\
\cline { 2 - 4 } & Total & 99 & 100 \\
\hline
\end{tabular}

Source: Researcher's Own Survey Results, March 2016

As the above Table 4.11 shows, only $34.3 \%$ the respondents replied positively and the highest percent of respondents $(65.7 \%)$ replied as they were not provided sufficient training on civil service reform implementation. In addition, key informants and focus group discussants also confirmed as civil servants were not given adequate training due to lack of finance for training and lack trainer on the reform program. Thus, based on the above data it is possible to conclude that, even though training has a great importance, civil servants/employees were not given regular training on civil service reform implementation in Haro Limu district. 


\section{Lack of Effective Communication}

Table 8. Respondents' Opinion on Effective Communication among public sectors

\begin{tabular}{|l|l|l|l|}
\hline \multicolumn{1}{|c|}{ Items } & Responses & Frequency & Percent \\
\hline \multirow{2}{*}{$\begin{array}{l}\text { Is there effective communication between public } \\
\text { sectors on civil service reform? }\end{array}$} & Yes & 24 & 24.2 \\
\cline { 2 - 4 } & No & 75 & 75.8 \\
\cline { 2 - 4 } & Total & 99 & 100 \\
\hline
\end{tabular}

Source: Researcher's Own Survey Results, March 2016

As it can be observed from the above Table, 4.14, regarding whether there is effective communication, $24.2 \%$ of the respondents said 'Yes' and $75.8 \%$ of them replied 'No' on the existence of effective communication between public sectors on civil service reform. Besides, majority of the key informants suggested that public sectors communication is poor and irregular in working together to realize the reform program. Thus it is possible to say lack of effective and regular communication between public sectors on civil service reform is a major problem for the implementation of civil service reform in the study area.

\section{Lack of Regular Supervision and Monitoring}

Table 9. Opinion of Respondents on Supervision and Monitoring

\begin{tabular}{|l|l|l|l|}
\hline \multicolumn{1}{|c|}{ Item } & Response & Frequency & Percent \\
\hline Is there regular supervision and monitoring on civil service reform? & Yes & 34 & 34.3 \\
\cline { 2 - 4 } & No & 65 & 65.7 \\
\cline { 2 - 4 } & Total & 99 & 100 \\
\hline
\end{tabular}

Source: Researcher's Own Survey Result March, 2016

As it is shown in the above Table, $34.3 \%$ of the respondents replied there is regular supervision while the greater percent $(65.7 \%)$ of the respondents replied there is lack regular supervision and monitoring on civil service reform. This data shows that there is poor supervision and monitoring on the implementation of civil service reform in the study area.

\section{CONCLUSION}

Based on the above discussions of the presented data, the following conclusions were made regarding the challenges in the implementation of CSR in Haro Limu district. Accordingly, this study identified that low commitment and low competency of top management officials and civil servants, and low cooperation between management officials and employees as problems hindering implementation of reform program in the study area. The findings of the study also revealed that due to lack of professionalism, lack of fair selection, evaluation and promotion of employees, and lack advanced measurement standards implementation of civil service reform is delayed in Haro Limu district.

Moreover, the study identified lack of adequate training, lack of incentives or rewards for employees, lack of effective communication between public sectors and lack of regular supervision and monitoring as considerable challenges affecting civil service reform implementation in the study area.

\section{RECOMMENDATIONS}

Since implementing civil service reform is difficult without the proper understanding and commitment of both top management officials and civil servants, strengthening capacity building is necessary. This includes enhancing commitment of management officials and employees, enhancing cooperation between top management officials and employees as well as between public sectors. In addition, ensuring the culture of accountability among public officials and public employees also need to be promoted. To this effect, the district and zonal administration should work together on training and awareness creation activities.

Enhancing human resource management by hiring employees based on merit system; appreciation of the employee's value, practicing fair evaluation and promotion of employees and rewarding of good performers in their respective activities are other ways that implementation of CSR can be realized. In addition since, implementing civil service reform without sufficient budget is unthinkable. Thus, Finance and Economic Development Bearou of the region in collaboration with MoFED should allocate adequate budget for civil service reform implementation. Finally this study point out that, strengthening regular supervision and monitoring as another important issue to be given consideration in realizing the civil service reform in the study area.

\section{References}

Abeje Tafere and E.A. Narayana, 2015. Civil Service in Amhara National Regional State, Ethiopia; Public Policy and Administration Research; Vol.5, No.2, 2015 (pp. 51-58)

C.R Kothari 2004. Research Methodology; Methods and Techniques, New Age International (P) Ltd., Publishers 
Emmanuel Lukumai. C, 2006. The Implementation of Civil Service Reforms in Tanzania, from 1991-2000: University of Bergen, Norway, Master's Thesis June 2006. Unpublished

Gebre Miruts and Melesse Asfaw, 2014. The Implementation of Civil Service Reforms in Ethiopia: The Promise for Civil Service De-Politicization of Tigray National Regional State. Developing Country Studies Vol.4, No.7 (pp.91-105)

J.W. Creswell, V.L. Plano Clark, 2007. Designing and Conducting Mixed Methods Research. Sage Publication University of Nebraska Lincoln, New Delhi, India, 2007

Libanos,et,al. 2014. The Implementation of Recruitment and Selection in Civil Service Institutions of Oromia National Regional State, Ethiopia, Journal of Environment and Earth Science Vol.4, No.13, 2014 (pp.61-67)

Paulos, C. (2001). The challenges of the civil service reform in Ethiopia: Initial observations. East Africa Social Science Research Review, XVII, (pp. 79-103)

Rahman.A.T. Rafiqur, 2001. Reforming the Civil Service for Government Performance: A Partnership Perspective, Dhaka: The University Press

Solomon Markos, 2013. Civil Service Reform in Ethiopia: Issues, Lessons, and Future Directions. International Journal of Public Administration, 36:4, 235-247, DOI: 